\section{B A Institute of \\ YK Business Administration \\ 帘 \\ Karachi \\ Leadership and Ideas for Tomorrow}

Business Review

Volume 15 Issue 2 July-December 2020

$1-15-2021$

\title{
Equity liquidity, firm investment and financial performance: An assessment of the role of financial development
}

\author{
Maria Karim \\ International Islamic University, Pakistan \\ Abdul Rashid \\ International Islamic University, Pakistan
}

Follow this and additional works at: https://ir.iba.edu.pk/businessreview

Part of the Finance Commons

\section{(c) (1)}

This work is licensed under a Creative Commons Attribution 4.0 International License.

\section{Recommended Citation}

Karim, M., \& Rashid, A. (2021). Equity liquidity, firm investment and financial performance: An assessment of the role of financial development. Business Review, 15(2), 51-74. Retrieved from https://doi.org/ 10.54784/1990-6587.1060

This article is brought to you by iRepository for open access under the Creative Commons Attribution 4.0 License and is available at https://ir.iba.edu.pk/businessreview/vol15/iss2/3. For more information, please contact irepository@iba.edu.pk. 


\title{
Equity liquidity, firm investment and financial performance: An assessment of the role of financial development
}

\author{
Maria Karim • Abdul Rashid
}

\begin{abstract}
This paper examines the impact of equity liquidity (EQLQ) on firm performance (FPER) and firm investment (FINV) decisions. It also examines whether financial sector development (FSD) decreases the importance of EQLQ for firms' financial performance and investment policy. An unbalanced panel dataset for 360 non-financial Pakistani firms covering the period 2001-2018 is used. The results suggest that increased EQLQ has significant positive impact on firms' investment decisions and financial performance. However, we find that enhanced FSD significantly reduces the investment-favoring and performanceenhancing role of EQLQ. The findings on the effects of EQLQ on both FINV and FPER are consistent with the several theoretical channels identified in literature. The evidence on the moderating role of FSD is also inline with our theoretical conjecture. The findings have several implications for investors, managers, and policymakers.
\end{abstract}

Keywords Equity liquidity - Firm performance $\cdot$ Firm investment - Financial development

\section{Introduction}

Understanding the linkages between EQLQ, FINV, and FPER is essential for academia, investors, firm managers, and policymakers. Why firms' stock liquidity is viewed an essential factor for determining the investment policy of corporate firms? How boosted stock liquidity decreases the uncertainty about acquiring funds from capital markets? Do firms that have more liquid stocks perform better? Does the higher level of liquidity of firms' stocks reduce the costs of issuing new equity? Does improved equity liquidity enhance the flow

Maria Karim

International Islamic University-Pakistan

E-mail: mkrim.bhatti@gmail.com

Abdul Rashid

International Islamic University-Pakistan

(C)Karim, M and Rashid, A. 2020 
and efficiency of information? Does equity liquidity lower default risk? Whether and how firm-specific characteristics and market factors help articulate the equity liquidity impacts? These research questions have generally encouraged both theorists and empiricists to investigate the influence of EQLQ on asset pricing, firm valuation, and different financial and economic policies.

Prior empirical investigations including Hovakimian et al (2004); Frieder and Martell (2006); Lipson and Mortal (2009); Udomsirikul et al (2011); ElBannan (2017); Nadarajah et al (2018); Chen et al (2020); Cheung et al (2020) have documented significant evidence that EQLQ has an essential role to play in determining firms' capital structure. The fundamental argument of these studies is that firms with liquid stocks can issue new equity at low costs and consequently, these firms decrease debt financing to finance their investments and other capital needs, decreasing significantly the leverage ratio. Likewise, some other studies analysis firms' equity issuance and document that when stock prices are high, then corporate firms are more expected to obtain capital by issuing new stocks (Dittmar and Thakor 2007; Stulz et al 2013). In the same vein, other researchers have reported that firms prefer to attain funds by issuing new equity to finance their assets in periods when their stock prices are higher (Asquith and Mullins Jr 1986; Mikkelson and Partch 1986; Baker and Wurgler 2002; Jung et al 1996). Researchers are also of the view that investment banks and other financial institutions usually charge a low fee for offering seasoned equities by firms that have relatively higher EQLQ (Butler et al 2005).

An important research question, which is not well answered in the literature concerning the impacts of stock liquidity is whether, how, and when EQLQ impacts firms' investment activities? Financial economic theories and the existing empirical literature suggest that EQLQ has an essential role to play in determining required returns on stocks (Kim and Lee 2014; Sadaqat and Butt 2017; Butt and Virk 2015). Rational investors generally demand "liquidity premiums" for doing investments in assets that are relatively illiquid. Moreover, early studies by Amihud and Mendelson $(1986,1988)$ have provided strong evidence that improved EQLQ favorably impacts firms' financial values. The value-enhancing impact of EQLQ is theoretically attributed to the fact that the cost of capital decreases when the liquidity of stock increases. Thus, firms' existing assets are discounted at a lower discount rate, which results in higher value. A large amount of empirical research has provided evidences that are consistent with these theoretical underpinnings (Haugen and Baker 1996; Easley and O'hara 2004).

Firms' stock liquidity has theoretically positive effects on FINV through mainly two different ways. According to the first mechanism, EQLQ stimulates firms' investment activities by positively affecting their market values. Further, boosted EQLQ enlarges the set of potential investment opportunities for corporate firms. In fact, as it is argued by an early study of Myers (1977), both the existing capital and other assets of firms and available investment prospects determine firms' values. Higher levels of EQLQ will result in lower required returns, which subsequently, will decrease capital costs, enabling firms to do more investment.

The second channel works through financial constraints faced by firms while 
obtaining funds from external sources. Improved EQLQ positively affects FINV by alleviating firms' credit constraints. Firms with more liquid equities are more likely to attain needed funds easily and comparatively at lower capital costs. As a result, they are expected to increase their investment expenditures. Similarly, firms having liquid stocks are also more prone to perform better as they may incur less costs of capital and have a higher value of assets. Departing from most existing empirical studies, in this paper, we empirically test the implications of the liquidity premium hypothesis and the information efficiency of stock prices in a relatively different way, specifically by inspecting the impacts of EQLQ on FINV and FPER in Pakistan.

Equity liquidity also affects firm value through mainly two mechanisms. First, the corporate governance channel is an important mechanism through which the liquidity of equity positively relates to firms' performance. Specifically, prior studies have documented that equity liquidity affects the financial performance of firms by improving corporate governance mechanisms over and above its effects on the investment opportunity set (Chen et al 2020). Another channel through which EQLQ positively impacts firms' value is the informational efficiency channel. Several studies including Diamond and Verrecchia (1981) and Holmström and Tirole (1993) have shown that stock liquidity improves the flow of information regarding equity prices. EQLQ also enables insiders to get more incentives by creating firm value (Faure-Grimaud and Gromb 2004). Moreover, the liquidity of equity enhances the involvement of shareholders in decisionmaking (Kyle and Vila 1991; Kahn and Winton 1998; Maug 1998; Noe 2002). Furthermore, the "market-to-book" value of firms (aka Tobin's Q ratio) and illiquidity both are negatively associated, suggesting that the improvement in liquidity results in increased firm performance. Said differently, firms with high profitability are more attractive for investors (Chung et al 2010). Given these arguments, one can expect that firms' financial performance will enhance as a result of increases in equity liquidity.

Another study by Fang et al (2009) shows that the enhanced EQLQ can improve firms' market value as the liquidity prompts trading activities of wellinformed and knowledgeable financial investors, both individual and institutional, which may result in more informative stock prices and enhance marginal incentives to investors and managers. Similarly, Xiong (2016) asserts that increased EQLQ may assist corporate firms to benefit all available potential opportunities for investments. Likewise, according to Fan et al (2012), the liquidity of stocks significantly impacts the profitability and performance of corporate firms. Other empirical studies including Becker-Blease and Paul (2006); Kang et al (2017); Amihud and Levi (2019); Alhassan and Naka (2020) have documented significant findings on the positive effects of EQLQ on firm-level investments.

The development of financial markets also plays a significant role in firms' financial decisions. FSD significantly affects firms' decisions whether to finance their assets and new investment projects by debt financing or by new equity issuance. FSD not only increases funds availability but also reduces the cost of debt financing. Further, financial sector development makes easy access to debt markets by lessening unnecessary regulations and high collateral requirements. Therefore, it is expected that the role of equity liquidity in determining firms' 
value and financial decisions will decrease with FSD in the economy. Higher FSD generally results in lower costs of borrowing, reducing the dependency and willingness of firms to issue new equities and thereby, the importance of equity liquidity for investment and growth objectives. Thus, firms may opt for debt financing to finance their investment and other working capital requirements to reduce overall costs of capital.

A careful review of the existing literature reveals that the effects of EQLQ on FINV and FPER are relatively less explored, specifically for emerging economies. Nevertheless, for in-depth and comprehensive understanding of whether, how, and when EQLQ impacts the financial and economic activities of firms, it would be useful to examine these issues for firms operating with different countries having different economic and financial environments. Definitely, empirical evidence on the EQLQ effects on FINV and FPER from different countries across the globe will help enhance our understanding regarding the significance of EQLQ for the process of the evaluation of firms and their financial policies. Empirical evidence on whether financial sector development has any role to play in establishing the equity liquidity effects on both firms' financial performance and investment decisions is also important to understand how financial markets' friction affects investment and performance sensitivity to equity liquidity.

Considering the gaps left in existing empirical literature, this paper aims to contribute by examining the role of EQLQ in explaining firms' investment and financial performance. The paper also examines whether financial sector development deteriorates the influence of EQLQ on the investment activities and financial performance of Pakistani corporate firms. We include several firmspecific control variables into the specifications to obtain the net marginal effect of EQLQ. Two different measures of EQLQ, viz. Pástor and Stambaugh (2003) measure of EQLQ, henceforth PS-liquidity measure and Amihud (2002) measure of EQLQ, hereafter AM-liquidity measure, are considered to ensure that the effects are not driven by any particular measure of liquidity. To take into consideration the dynamic nature of the panel data set and to mitigate the problem of endogeneity in the equity liquidity phenomenon, we apply the robust two-step system GMM estimator, henceforward system-GMM estimator.

Although we build upon the work of Rashid and Karim (2018) on the effect of equity liquidity on performance, this paper significantly departs from their study and expands the existing literature in several aspects. For instance, the objective of this paper is to examine the impact of equity liquidity on both firm investment and financial performance and to study whether and how financial sector development influences these effects. However, Rashid and Karim (2018) only scrutinize the effects of EQLQ on performance; they neither study the application of equity liquidity for firms' investment policy nor securitize the moderating role of FSD for shaping the equity liquidity effects. Whilst examining the impacts of equity liquidity they estimate a static firm-performance model. Nevertheless, we estimate dynamic investment and performance models to control for inertia in firms' behaviors. Finally, they apply fixed effects estimator by ignoring the presence of potential endogeneity issues, whereas, we estimate the proposed empirical models by applying the system-GMM estimator to alleviate endogeneity problems. 
Equity liquidity, firm investment and financial performance...

The findings of the paper show that boosted equity liquidity significantly stimulates firm investment and enhances firm financial performance. The findings also suggest that increased FSD significantly reduces firms' dependency on equity liquidity while making investment decisions and achieving higher performance objectives. By presenting strong findings on the EQLQ effects on the investment decision and performance of firms, we complement the literature, supporting the liquidity premium hypothesis, the informational efficiency channel, and the corporate governance channel. We also expand to the existing literature on the effects of FSD on the profitability of firms and the costs of external capital by providing significant evidences on the function of financial advancements in articulating the influence of stock liquidity on firm investment policy and financial performance. Specifically, the findings suggest that given that the other factors are constant, the higher the FSD, the lower the importance of EQLQ for FINV and FPER.

The rest of the paper is planned as follows. Section 2 presents theoretical rationalizations, empirical literature review, and formulation of hypotheses for the effects of EQLQ. Section 3 presents data description, variable construction, and empirical methods. Section 4 displays the empirical findings and presents their discussions. Section 5 presents some conclusions and policy implications for different stakeholders.

\section{Theoretical justifications, empirical literature review and hypotheses}

Researchers have identified several channels, both theoretically and empirically, through which the liquidity of stock influences corporate firms' value and financial decisions. These channels include the informational efficiency channel, the corporate governance channel, the liquidity premium hypothesis, the default risk channel, and the alleviating financial constraints channel. The existing empirical studies have also provided significant evidences on the effects of EQLQ on corporate firms' capital structure decisions, dividend policy, firm value, investment decisions, and asset pricing. Below, we present a concise review of the studies on the EQLQ effects.

The phenomenon of EQLQ and its role in asset price determination was first time presented in the seminal work of Amihud (2002). The author provides insights that rational investors mostly require higher returns for investing in stocks that are relatively illiquid. This proposition implies that stocks' liquidity is adversely related to the costs of equity issuance. After this initiative, several studies have investigated the equity liquidity effects from several different aspects. For instance, Baker and Wurgler (2002) provide evidence that prices of stocks implicitly influence the investment decisions of firms that are highly equity dependent. Another study by Corwin (2003) finds that stock market liquidity is negatively related to the pricing of seasoned equity offerings by corporate firms. Hennessy and Whited (2005) provide insight that higher levels of EQLQ make firms relaxed and comfortable to obtain funds by issuing new equity as the liquidity lowers costs for equity issuance. Likewise, Butler et al 
(2005) also document empirical findings showing that equity market liquidity significantly affects the decisions of firms to acquire capital through external markets. However, Choi and Cook (2006) show that stock market liquidity provides information that enable firm managers to enhance the efficiency of their investments.

Becker-Blease and Paul (2006) also find positive interactions between EQLQ and firms' investments. Particularly, they show that EQLQ effectively and considerably expands the set of projects having positive NPVs that enables and motivates firms to spend more on capital assets. This finding suggests that firms having more liquid stocks are expected to do more investments. Firms may do so because EQLQ significantly lowers the costs associated with the issuance of equity. Frieder and Martell (2006) show that EQLQ significantly and positively affects firms' capital structure decisions. Specifically, the findings of their study reveal that firms with relatively more liquid stocks opt to use less debt to finance their assets. The negative stock liquidity-debt relation is generally inline with the view that enhanced EQLQ lowers the cost of equity and thus, firms prefer equity issuance over debt financing to finance their capital needs. Yet, an early study by Anderson (2002) documents evidence of the positive effects of equity liquidity on debt financing. The positive effects on leverage of equity liquidity are mainly attributed to the default-risk-reduction role of stock liquidity. Further, as it is mentioned above, the differences in leverage effects are also important in shaping equity liquidity effects on firms' leverage decisions.

Another empirical investigation by Dittmar and Thakor (2007) shows that firms prefer to issue equity to debt financing when their stock prices are higher, suggesting that stock liquidity and capital costs are negatively linked. Likewise, Stulz et al (2013) empirically find that corporate firms' decisions to issue new equity to finance their capital needs are influenced by stock market liquidity. Kim and Lee (2014) estimate the "liquidity-adjusted capital asset pricing model" and show that EQLQ is significantly priced in the stock market. This implies that the higher the EQLQ the lower the required return.

Kang et al (2017) analyze how EQLQ affects firms' investment behavior and find that the liquidity of stocks positively impacts firms' investment spending. Likewise, Zhang et al (2018) find that stock market liquidity and firms' market value measured by Tobin's Q are positively associated, suggesting that equity liquidity has significant applications for corporate firms. Similarly, some early studies have also documented positive, significant effects of equity market liquidity on firms' market value and financial performance. For example, according to Arian et al. (2014), EQLQ is insignificantly related to the market value of companies. Dalvi et al (2014) provide robust and significant evidence indicating the positive effects of EQLQ on FPER. Firms having more liquid stocks may incur less costs of capital, which, subsequently, positively affects their productivity and profitability.

Singh et al (2015) also examine the EQLQ effects and show that higher liquidity is positively and significantly linked with firm performance. Cheung et al (2015) study the effects of EQLQ and show that liquidity has positive impact on the market value of firms. They further show that stock liquidity has a critical role in improving corporate governance by increasing institutional ownership. 
Equity liquidity, firm investment and financial performance...

This finding indicates that over and above the direct effect of equity liquidity, there are some other channels through which the liquidity may affect firms' financial decisions and performance.

ElBannan (2017) examines the role of EQLQ in defining the capital structure of Egyptian corporate firms and finds that it does not have any statistical significant effect on leverage. Brogaard et al (2017) find that higher EQLQ significantly lowers the risk of default. They assert that this role of equity liquidity mainly works through its positive effects on stock price information and on corporate governance. Rashid and Karim (2018) working on a panel of Pakistani firms show that EQLQ is significant in determining FPER. Nadarajah et al (2018) relate the stock liquidity to the leverage decisions of firms in Australia. They show that enhanced liquidity significantly increases firm leverage. They further show that the level of corporate governance is significant in determining the stock liquidity-leverage association.

Amihud and Levi (2019) explore the effect of EQLQ on firms' investment and production decisions. They find that by increasing the cost of capital, stock illiquidity reduces firm investment. They also show that these effects of stock liquidity even hold for financially constrainted firms. Batten and Vo (2019) inspect the effects of EQLQ on the market value of firms in Vietnam and contrary to many prior studies, find that it is negatively, significantly related to firm value. They assert that this conflicting result may be due to the difference in leverage effect in developed and developing countries. Alhassan and Naka (2020) provide robust evidence on the positive influence of EQLQ on firms' future investment decisions. Nevertheless, they show that this relation is highly affected by financial market development and financial constraints.

Recently, Cheung et al (2020) examine the impact of EQLQ on the debtequity choice of corporate firms and find that firms with relatively liquid stocks are more expected to finance their investments through debt financing. They also show that compared to equity cost, the cost of debt is more affected by EQLQ. Given the theoretical framework of financing in the presence of information asymmetries and uncertainties, these findings apply that higher equity liquidity facilitates information production, which, in turn, decreases insider trading and market uncertainty regarding firms' potential cash flow streams, thereby, lowers the risk of bankruptcy and consequently, the debt costs of corporate firms.

Chen et al (2020) explore the effects of EQLQ on firm leverage and find that higher levels of stock liquidity significantly lower firms' excess leverage, mainly through the channel of informational efficiency and the channel of blockholders. These findings also confirm the significant role of equity liquidity in firms' financial decisions and thereby on firms' financial performance. Butt and Virk (2015) estimating the liquidity-adjusted-asset-pricing model show that EQLQ has an essential role in determining risk premiums and thus, the required rate of return on risky assets. Similar findings are reported by Sadaqat and Butt (2017) for Pakistan's equity market using firm-level data. These findings imply that EQLQ is significantly, negatively related to the cost of equity issuance and thus, firm investment and leverage decisions.

After reviewing the existing studies on the effects of EQLQ on firms' finan- 
cial decisions we can draw the following conclusion. First, EQLQ significantly reduces capital costs by lowering required returns on equity. Second, EQLQ negatively affects the default risk by improving the informational efficiency, inducing firms to increase use of debt financing. Third, equity liquidity considerably expands the pool of feasible investment opportunities for firms having liquid stocks. Fourth, EQLQ is an important-priced factor in asset-pricing context, complementing the liquidity premium phenomenon. Fifth, we find handfull studies showing significant positive links between EQLQ and the investment strategies of firms. Finally, there are also some studies that have provided strong empirical evidences, indicating the positive, significant association between EQLQ and both market value and financial performance of corporate firms.

We observe that most prior studies have investigated the EQLQ effects on firms' financial decisions largely for developed economies. Thus, we have relatively limited empirical evidence on the EQLQ impacts on the performance and investment strategies of firms in both emerging and developing economies. Further, we observe that most of previous empirical studies have investigated whether and how equity liquidity impacts firm value, asset pricing, and leverage decisions, whereas, relatively less empirical work has been done to explore the impacts of EQLQ on investment decisions. Nonetheless, the empirical investigation of the EQLQ effects on the investing decisions of corporate firms is worthwhile as several theories predict that equity liquidity improves stock price based information production, corporate governance, reduces default risk, expands investment opportunity set, and lowers costs of capital and thus, increases firms' investment in capital assets.

Last but not the least, despite the large amount of empirical work on the impacts of equity liquidity, the existing empirical literature is almost silent regarding the role of different firm-specific and market factors in determining the equity liquidly effects on firm investment and performance. Particularly, we do not find any study that examines whether and how financial sector development plays a role in formulating the influence of EQLQ on firm performance and investment. One should note that a recent study by Alhassan and Naka (2020) is an exception that examines the effects of EQLQ on investment at different levels of financial development. Yet, the paper in hand significantly departs from their study as it expands the investment and performance models by including the interaction between the equity liquidity measure and the variable financial sector development, whereas, Alhassan and Naka (2020) generate the dummy variables by grouping the sample countries into least developed, medium developed, and most developed countries. Further, they only examine the role of financial development for the equity liquidly-investment sensitivity, whereas, this paper aims to scrutinize how the development of financial sectors affects the impact of equity liquidity on both FINV and FPER. Based on the above mentioned theoretical predictions and empirics on the effects of equity liquidity we construct the following four hypotheses for this paper.

H1: Given the impact of other factors, the liquidity of a firm's stock significantly, positively affects its investment spending.

H2: Given the influence of other factors, the financial sector development sig- 
Equity liquidity, firm investment and financial performance...

nificantly decreases the sensitivity of a firm's investment decisions to its equity liquidity.

H3: Given the effects of other factors, the liquidity of a firm's stock significantly improves its financial performance.

H4: Given that the other factors are constant, financial sector development significantly decreases the firm performance-enhancing role of equity liquidity.

\section{Empirical framework}

To test the constructed hypotheses, we utilize an unbalanced annual panel data set of 360 non-financial Pakistani firms. These firms are listed on the "Pakistan Stock Exchange (PXS)" during the period 2001 to 2018. To combat the survival bias, we permit entry and exit of firms. All firm-level variables are obtained from the "Balance Sheet Analysis of Non-Financial Firms" printed by the State Bank of Pakistan (SBP). Money supply and GDP data are taken from "World Bank Indicators" and "World Bank Database".

We estimate several different specifications of FINV and FPER to attain the set objectives of the paper. A one-period lag of investment is considered as an explanatory variable to take into consideration the dynamic nature of the investment spending of firms. We also control for firm-specific time invariant and year-specific effects. The model takes the following form:

$$
\begin{aligned}
F I N V_{i t} & =\beta_{1}+\beta_{2} F I N V_{i t-1}+\beta_{3} E Q L Q_{i t-1}+\beta_{4} F C F_{i t-1}+\beta_{5} T Q_{i t-1} \\
& +\beta_{6} \text { Lev }_{i t-1}+\beta_{7} \text { Size }_{i t-1}+\beta_{8} C H_{i t-1}+\beta_{9} \text { Div }_{i t-1}+\beta_{10} \text { Age }_{i t-1} \\
& +\beta_{11} \text { BR }_{i t-1}+f_{i}+y_{t}+\epsilon_{i t}
\end{aligned}
$$

where $F I N V_{i t}$ is firm investment, $E Q L Q$ is the underlying equity liquidity measure, $F C F$ is free cash flow, $T Q$ is Tobin's Q ratio, Lev is financial leverage, Size is firm size, $C H$ is the ratio of cash holdings, Div is the ratio of cash dividends, $A g e$ is firm age, $B R$ is business risk, $f_{i}$ is firm-specific time-invariant effects, $y_{t}$ is year-specific effects, and $\epsilon_{i t}$ is the error term. Table 1 presents the operational definition of the variables.

To achieve the second objective of the paper whether equity liquidity significantly affects firm performance, we estimate the following specification:

$$
\begin{aligned}
F P E R_{i t} & =\beta_{1}+\beta_{2} F P E R_{i t-1}+\beta_{3} E Q L Q_{i t-1}+\beta_{4} F C F_{i t-1}+\beta_{5} T Q_{i t-1} \\
& +\beta_{6} L_{i t-1}+\beta_{7} \text { Size }_{i t-1}+\beta_{8} C H_{i t-1}+\beta_{9} T A N_{i t-1}+\beta_{10} \text { Age }_{i t-1} \\
& +\beta_{11} B R_{i t-1}+f_{i}+y_{t}+\epsilon_{i t}
\end{aligned}
$$

where FPER is the return on assets. TAN is the tangibility of firms and all the other variables are same as in Eq. (1).

Financial sector development allows easy access to debt markets by lessening unnecessary regulations and high collateral requirements. Given this, we expect that the sensitivities of firm investment and financial performance to equity liquidity decline with FSD in the economy. To test this hypothesis, we expand the model presented in Eq. (1) and Eq. (2) by adding the interaction terms 
between the equity liquidity measure and the proxy of FSD. We title this model as "the interacted model". The models take the following form:

$$
\begin{aligned}
F I N V_{i t} & =\beta_{1}+\beta_{2} F I N V_{i t-1}+\beta_{3} E Q L Q_{i t-1}+\beta_{4} E Q L Q \times F S D_{i t-1} \\
& +\beta_{5} F S D_{t-t}+\beta_{6} F C F_{i t-1}+\beta_{7} T Q_{i t-1}+\beta_{8} L e v_{i t-1}+\beta_{9} S_{i z e_{i t-1}} \\
& +\beta_{10} C H_{i t-1}+\beta_{11} D_{i v_{i t-1}}+\beta_{12} \text { Age }_{i t-1}+\beta_{13} \text { BR }_{i t-1}+f_{i}+y_{t}+\epsilon_{i t}
\end{aligned}
$$

To test whether FSD influences EQLQ effects on FPER, we estimate the following specification:

$$
\begin{aligned}
F P E R_{i t} & =\beta_{1}+\beta_{2} F P E R_{i t-1}+\beta_{3} E Q L Q_{i t-1}+\beta_{4} E Q L Q \times F S D_{i t-1} \\
& +\beta_{5} F S D_{t-t}+\beta_{6} F C F_{i t-1}+\beta_{7} T Q_{i t-1}+\beta_{8} T A N_{i t-1}+\beta_{9} L e v_{i t-1} \\
& +\beta_{10} \text { Size }_{i t-1}+\beta_{11} C H_{i t-1}+\beta_{12} \text { Age }_{i t-1}+\beta_{13} B R_{i t-1}+f_{i}+y_{t}+\epsilon_{i t}
\end{aligned}
$$

The endogeneity problem is highlighted in literature on the impact of equity liquidity. It is highly likely that any shock affecting firms' investment and financial performance may also affect firms' stock liquidity. Therefore, to overcome the problem of endogeneity and to take into account the dynamic nature of our investment and performance models, we use "the two-step system GMM estimator" proposed by Blundell and Bond (1998).

On one hand, this estimator removes all time-invariant effects by transforming the model in first-difference form. On the other hand, it retains the variability in the variables by estimating simultaneously both the level and firstdifference equations of the model. Further, it allows researchers to use different lags of variables in levels and in their first differences as the instruments. Yet, to obtain robust results, the instruments used in the estimation should be valid and not be related to the error term. Therefore, to check whether the instruments are orthogonal to the error term, we employ the J-test proposed by Hansen and Wernerfelt (1989). Further, to obtain reliable estimation results, the estimated residuals of the model should be free from the second-order autocorrelation. Therefore, to ensure the absence of the second-order serial correlation in the residuals, we apply the "Arellano-Bond AR (2)" test. We use robust standard errors to draw robust statistical inference.

\subsection{Gauging equity liquidity}

\subsubsection{Pastor and Stambaugh's measure}

Pástor and Stambaugh (2003) assert the illiquidity of stocks is positively related to required returns. They propose a liquidity measure, which reflects the cost of trading. PS-liquidity measure can be implemented in three steps. First, we estimate the model given in Eq. (5) by applying ordinary-least-square estimator.

$$
\begin{array}{r}
R_{i, d+1, t}^{e}=\alpha_{i t}+\beta_{i t} \times R_{i, d, t}^{e}+\lambda_{i t} \times \operatorname{sign}_{i, d, t}^{e} \cdot T V_{i, d, t}+\epsilon_{i, d+1, t} \quad(5) \\
d=1,, D
\end{array}
$$


Equity liquidity, firm investment and financial performance...

\begin{tabular}{|c|c|c|}
\hline Symbol & Variable names & Description \\
\hline$F I N V_{i t}$ & Investment of firms & $\begin{array}{l}\text { Capital expenditures scaled by book assets of } \\
\text { firms. }\end{array}$ \\
\hline$E Q L Q_{i t}$ & Equity liquidity & $\begin{array}{l}\text { Pastor and Stambaugh's measure of equity liq- } \\
\text { uidity and Amihud's measure of stock liquidity. }\end{array}$ \\
\hline$F C F_{i t}$ & Free cash flow & Cash flow from operations scaled by total assets. \\
\hline$T Q_{i t}$ & Tobin's Q ratio & Market to book value scaled by total assets. \\
\hline $\operatorname{Lev}_{i t}$ & Financial leverage & Total liabilities scaled by total assets. \\
\hline Size $_{i t}$ & Firm size & Log of firm assets normalized by CPI. \\
\hline $\mathrm{CH}_{i t}$ & Cash holdings & Cash holdings to assets. \\
\hline Div $_{i t}$ & Dividend & The ratio of cash dividends to assets. \\
\hline$A g e_{i t}$ & Firm age & $\begin{array}{l}\text { Number of years in the given year the firm is in } \\
\text { the business. }\end{array}$ \\
\hline$B R_{i t}$ & Business risk & Standard deviation of cash flows. \\
\hline$R O A_{i t}$ & Return on assets & Net income scaled by assets. \\
\hline$T A N_{i t}$ & Tangibility of firms & $\begin{array}{l}\text { Expenditures on plant, property, and equipment } \\
\text { scaled by assets. }\end{array}$ \\
\hline$F S D_{t}$ & Financial development & The money supply-to-GDP ratio. \\
\hline
\end{tabular}

where $R_{i, d, t}$ is the return on stock $i$ on day $d$ in month $t, \alpha_{i t}$ is stock-specific intercept in month $t, \beta_{i t}$ is the coefficient of $R_{i, d+1, t}^{e}$, and $\lambda_{i t}$ is the liquidity measure for the $i t h$ stock. $R_{i, d+1, t}^{e}$ is the difference between $R_{i, d, t}$ and $R_{m, d, t}$, where $R_{m, d, t}$ is the market return, $T V_{i, d, t}$ is trading volume, sign $R_{i, d, t}^{e}=1$ if $R_{i, d, t}>0,=-1$ if $R_{i, d, t}<0$, and $=0$ if $R_{i, d, t}=0$.

The estimated value of the coefficient of the variable $\operatorname{sign} R_{i, d, t}^{e} \cdot T V_{i, d, t},\left(\hat{\lambda_{i t}}\right)$, is the EQLQ measure. This coefficient is estimated for each stock. The sign of $\hat{\lambda_{i t}}$ would generally be negative. However, the larger absolute value of $\hat{\lambda_{i t}}$ will represent lower EQLQ. To gauge EQLQ, month-wise OLS-regression model is estimated only for stocks that are traded for a minimum of 15 days in the given month. As a second step, the liquidity innovations can be estimated by using the following expression:

$$
\Delta \hat{\lambda_{i t}}=\left(m v_{i t} / m v_{i 1}\right) \times \hat{\lambda_{i t}}-\hat{\lambda_{i t-1}}
$$

$i=1, N_{t}$

where $m v_{i t}$ is ith stock's market value and $m v_{i 1}$ is its value in the first month. This sort of scaling takes into account the time value of liquidity, making the underlying EQLQ measure price-adjusted. Finally, the following regression is run to obtain the serially uncorrelated residuals.

$$
\Delta \hat{\lambda_{i t}}=\alpha+\beta \Delta \hat{\lambda_{i t-1}}+\delta\left(m v_{i t} / m v_{i 1}\right)-\hat{\lambda_{i t-1}}+\mu_{i t}
$$

The liquidity innovations are defined as the estimated value of the residuals from Eq. (7) scaled by 100. Specifically, it is defined as: SP-liquidity measure = $\hat{\mu_{i t}} / 100$ 


\subsubsection{Amihud's measure}

Amihud (2002) proposes an illiquidity measure, which can be estimated as follows:

$$
I L L I Q_{i t}=\frac{1}{D_{t}} \Sigma_{d=1}^{D_{t}}\left|R_{i t d}\right| /\left(T V_{i t d} / N_{i t}\right)
$$

$i=1, N_{t}$

where $I L L I Q_{i t}=$ measure of illiquidity, $D_{t}=$ total trading days in month $t, N_{i t}$ $=$ number of stocks, $R_{i t d}=$ return on stock $i$ in month $t$ on day $d,\left(T V_{i t d} / N_{i t}\right)=$ average trading volume. The illiquidity measure, $I L L I Q_{i t}$, is multiplied by -1 to get the liquidity measure, which is denoted by AM-liquidity measure.

\section{Empirical findings}

\subsection{Summary statistics}

Table 2 presents summary statistics for equity liquidity measures and other variables included in the empirical analysis. The firms make an investment of about $13 \%$ of their total assets in fixed capital assets on average. The standard deviation of investment indicates that FINV significantly varies across the firmyear observations. The mean of FPER is about $10 \%$. The mean value of PSliquidity measure is 0.3324 , whereas, the corresponding figure for AM-liquidity measure is 0.5420 , though, the standard deviation indicates that PS-liquidity measure has relatively more variation. It is also observed that the mean of cash flows and Tobin's Q ratio is 0.1123 and 3.4239, respectively.

The debt ratio has a mean of $24.59 \%$ with the SD value of 0.3254 , revealing that on average, firms finance about $25 \%$ of their total assets by debt financing. Firms hold about $4.6 \%$ of total assets in reserves. The mean of firm size is 15.870 . A firm's average life is 32.435 years. It is also observed that on average, the sample firms pay $2.76 \%$ of total assets in form of cash dividends to shareholders. The mean value of firm tangibility is 0.7832 with the SD value of 0.4675 . Finally, the mean value of business risk is 0.1258 . The mean and standard deviations indicate that there are significant variations in both liquidity measures as well as in the other variables considered for the empirical analysis of this paper.

\subsection{Correlations}

To obtain the primary evidence on the association between dependent variables and the set of explanatory variables, table 3 presents correlations. Both EQLQ measures are positively related to FINV and FPER. The positive correlation suggests that both firm investment and financial performance increase with the liquidity of their stocks. Likewise, the variables firm size and Tobin's Q both are positively correlated with FINV. This positive association suggests that large firms and firms with higher value of Tobin's Q do more investment spending on fixed assets. 
Equity liquidity, firm investment and financial performance...

Table 2: Summary statistics

\begin{tabular}{lcc}
\hline Variables & Mean & Std. Dev. \\
\hline Investment (FINV) & 0.128 & 0.316 \\
ROA (FPER) & 0.104 & 2.243 \\
PS-Liquidity Measure & 0.332 & 0.768 \\
AM-Liquidity Measure & 0.542 & 0.026 \\
Cash Flow & 0.112 & 0.119 \\
Tobin Q & 3.424 & 3.564 \\
Size & 15.870 & 2.988 \\
Leverage & 0.246 & 0.325 \\
Cash Holding & 0.047 & 0.099 \\
Dividends Ratio & 0.028 & 0.090 \\
Age & 32.435 & 15.878 \\
Tangibility & 0.783 & 0.468 \\
Business Risk & 0.126 & 0.169 \\
\hline
\end{tabular}

Note: Summary statistics are obtained by considering the firm-year observations included in the regression analysis.

However, the correlation coefficient for firm size and FPER is negative, implying that large firms are relatively less profitable. Although leverage is negatively related to investment, it is positively, significantly related to ROA. The positive leverage-investment correlation suggests that firms having more debt in their capital structure are less likely to do investment. However, firms' cash holdings have a significant correlation with both FINV and FPER. This evidence is consistent with the view that firms that hold more cash in their hands do less investment spending. The correlations between firm age and both FINV and FPER are negative. It is also evident that business risk is inversely related to FINV, although, it is positively and significantly correlated with FPER. Finally, it is observed that FSD is significantly positively correlated to both FINV and FPER.

Table 3: Correlations

\begin{tabular}{lcc}
\hline & Investment (FINV) & ROA (FPER) \\
\hline PS-Liquidity Measure & $0.1698^{* * *}$ & $0.0478^{* * *}$ \\
AM-Liquidity Measure & $0.1213^{* * *}$ & $0.0567^{* * *}$ \\
Cash Flows & $0.0316^{* *}$ & $0.3546^{* *}$ \\
Tobin Q & $0.0214^{*}$ & $0.0087^{*}$ \\
Size & $0.0997^{* *}$ & $-0.0375^{* *}$ \\
Leverage & $-0.0765^{* *}$ & $0.0596^{* *}$ \\
Cash Holding & $-0.0314^{* *}$ & $-0.2701^{* *}$ \\
Dividend Ratio & $-0.0132^{*}$ & $0.05408^{* *}$ \\
Age & $-0.0570^{* *}$ & $-0.0110^{*}$ \\
Tangibility & $0.0027^{*}$ & $-0.0378^{* * *}$ \\
Business Risk & $-0.1709^{* *}$ & $0.5713^{* * *}$ \\
FSD & $0.1763^{* * *}$ & $0.0546^{* *}$ \\
\hline
\end{tabular}

Note: $*, * *$, and $* * *$ denote significance at the $10 \%, 5 \%$ and $1 \%$ level, respectively. 


\subsection{Equity liquidity and investment}

To test the first hypothesis of the paper, we run two panel regression models for FINV. In Model 1, we consider PS-liquidity measure while in Model 3 we include AM-liquidity measure. We consider two different measures of EQLQ to ensure our findings are robust and not driven by a specific measure of stock liquidity. Table 4 presents the estimation results by applying the two-step robust GMM estimator. The estimated values of diagnostic tests provide strong evidence of the robustness of the estimation results. Specifically, the Hansen test indicates that the instruments applied in the estimation of all four models are orthogonal to the error term. Similarly, the $\operatorname{AR}(2)$ test indicates that the results do not exhibit any second order serial correlations. However, the AR(1) test confirms the presence of first order serial correlations in the estimated residuals, confirming the dynamic nature of the investment models. The estimated coefficient of a one-period lagged investment is positive and statistically significant at the $1 \%$ level in all the estimated models, signifying that there is a significant persistence in the investment behaviors of firms. The significant persistence confirms the dynamic nature of FINV models.

The estimated coefficients indicate that EQLQ is positively and statistically significantly related to FINV. These findings hold for both measures of EQLQ considered in this paper, confirming that the effects of EQLQ are not driven by any specific measure of liquidity; rather they are attributed to different theoretical channels explained in the literature. Although both EQLQ measures are positively related to firm investment, the magnitude of the estimated coefficient depends on the EQLQ measure. Specifically, we observe that the coefficient of PS-liquidity measure is 0.495 , whereas the corresponding coefficient for AMliquidity measure is 0.443 . These results reveal that the investment spending of Pakistani corporate firms increases with the liquidity of their stocks. The results of the control variables are consistent with the expectations and are generally similar to that of most previous studies.

In Model 1, the estimated coefficient of PS-liquidity measure is positive and significant at the $1 \%$ level. This finding implies that firms that have liquid stocks do more investment, on average. Firms with liquid stocks do more investments because they may relatively easily acquire needed amounts of capital by issuing new equity as their stocks are more traded in the market and investors may require fewer premiums, decreasing the cost of capital. The positive effect of EQLQ on investments implies that the liquidity is an important factor in determining corporate firms' investment decisions. Further, the positive equity liquidity-investment relation suggests that by improving EQLQ, corporate firms can decrease costs of capital and thus, increase investment. The finding of the positive effect of EQLQ on investment is consistent with $\mathrm{H} 1$, which states that given the effects of other factors, the liquidity of a firm's stock significantly increases its investment spending. The finding of the positive role of EQLQ in enhancing firm-level investment is also similar to the findings of Amihud and Levi (2019) and Alhassan and Naka (2020).

The positive sensitivity of investment to EQLQ can be justified through several theoretically well-established channels. One of the possible reasons for the 
positive effect of EQLQ is that the enhanced liquidity not only increases market value of assets but also enlarges opportunity set of potential investments. Thus, firms that have relatively liquid stocks are more expected to do investments in capital assets. The positive equity liquidity-investment relation is also consistent with the view that improved EQLQ results in lower costs of capital by decreasing required rate of return on stocks. Lower costs of capital motivate firms to increase their investment expenditures. The positive impact on investment of EQLQ can also be justified as higher liquidity lessens financial constraints and thus, firms can easily acquire required amount of capital by issuing new equity to capitalize available investment opportunities. Scholars are also of the view that increased EQLQ not only decreases the default risk but also improves the flow and quality of stock price information, which encourage firms to do more investments.

The results also indicate that FCF, Tobin's Q, and Size have positive, significant impacts on FINV. In contrast, the cash ratio, leverage, dividend ratio, firm age, and business risk are negatively related to FINV. The positive association between Tobin's Q and FINV is consistent with the view that firms with higher growth opportunities are expected to do more investments. This finding complements the finding of Beck and Levine (2004) that shows the positive relationship between FINV and growth prospects.

The findings suggest that FINV increases with firm size. One of the possible explanations is that larger firms usually have improved human capital and experience higher economies of scale and scope. Consequently, they invest more. Several other studies including Rashid (2011), Soumaya (2012), and Rashid and Saeed (2017) also report the positive effects of firm size on FINV. The results also reveal that firms with higher free cash flow are expected to invest more. This result supports the free cash flow hypothesis, asserting that firms that have extra cash flows are anticipated to spend more on capital assets. Moreover, the positive effects of free cash flow on FINV are generally consistent with the results of prior studies (Guariglia 2008; Soumaya 2012; Ogawa 2015).

The negative effect of leverage on FINV is consistent with Ogawa (2015). Highly levered firms may face difficulty to acquire additional short-term and long-term debt to finance their investments and other capital needs. Thus, they cut their investment spending. Consistent with Rashid and Saeed (2017), the results reveal that business risk is negatively related to firm investment, suggesting that firms significantly cut their investment spending in periods when they become uncertain about their earnings/cash flows. Higher levels of business risk result in higher default risk and higher cost of raising capital from external sources. Therefore, firms facing higher business risk reduce their investment.

The results of panel regression (Model 3), where we consider AM-liquidity measure are generally consistent with the results of Model 1. Specifically, we find that the estimated coefficient of EQLQ is positive and significant at the $1 \%$ level. This finding reveals that EQLQ has a positive and significant impact on FINV. This indicates that the finding of the positive impact of EQLQ on FINV holds for different proxies of liquidity. 
After having established the direct impact of EQLQ on investment decisions we examine whether and how financial development affects the equity liquidityinvestment sensitivity. To achieve this objective of the paper, we conjecture that given that all other factors are constant, financial sector development significantly decreases the sensitivity of a firm's investment decisions to its equity liquidity. Said differently, the impact of EQLQ on investment decreases as financial development increases. We predict this because firms' reliance on equity to obtain new capital decreases as debt financing becomes relatively cheaper and easy to obtain due to the occurrence of FSD in the economy. To examine this hypothesis, we multiply the equity liquidity measures with the proxy used for FSD. The estimation results of the interacted model are given in table 4 under the label of Model 2, where we use PS-liquidity measure of stock liquidity and for Model 4, we use AM-liquidity measure. The estimation results of control variables in both models are generally similar to the results of Model 1 and Model 3. Therefore, to economize on space, we do not do any commentary on these results. Rather, we focus on the estimated coefficient of the interaction term.

The estimated coefficient of the interaction term is negative and appears statistically significant in both models at the $1 \%$ level, indicating that the positive impact of EQLQ on FINV spending becomes weaker due to FSD in the economy. Specifically, in Model 2, we observe that the estimated value of the coefficient of interaction term $(-0.014)$ is negative while the estimated value of coefficient of EQLQ measure (0.565) is positive. Taken together, these estimates suggest that the positive sensitivity of FINV to EQLQ decreases with the development of overall financial sector. This finding holds in both Model 2 and Model 4, suggesting the moderating role of FSD is robust to different measures of EQLQ.

The evidence on the weaker effect of EQLQ on investment due to improved FSD in the economy is consistent with the second hypothesis of the paper: The higher the level of FSD, the lower the positive sensitivity of the investment to the equity liquidity. A possible explanation for such findings is that firms' dependence on equity decreases when debt becomes a cheaper source of financing due to FSD in the economy. Another possible justification for the moderating role of FSD in shaping the effect of EQLQ on FINV is that FSD reduces the overall cost of capital by making easy firms' access to external capital, which reduces the role of EQLQ in determining firms' investment decisions. These findings also suggest that improved FSD reduces firms' reliance on issuing new equity to finance their investments. There is also possibility that FSD reduces information asymmetry and adverse selection problem. Therefore, in developed financial markets, firms depend less on stock price based information while making investment decisions.

The direct effect of FSD is positive and appears statistically significant at the $5 \%$ level in both models, implying that firms do more investment as FSD increases. Because we utilize the money supply-to-GDP ratio as the proxy for FSD and thus, our findings imply that when the supply of money relative to 
GDP increases in the economy, the level of price also increases. The increased prices make firms more profitable and enhance overall economic activities in the economy and thus, they may increase their investment spending. Further, as we said above, FSD reduces the costs of external capital and makes more funds available for corporate firms. Thus, firms increase their investment expenditures as they can easily obtain the required capital from external sources.

In Model 2 and Model 4, based on the AR (2) tests, we do not find any significant evidence of the second-order serial correlation in the estimated residuals of the models. However, the AR(1) test confirms the first-order autocorrelation in the residuals, which provides support to our estimation of the dynamic investment model. The Hansen J-test statistic provides evidence that our set of instruments is valid as they appear orthogonal to the estimated residuals of the model. Thus, our results of the panel regressions are robust.

\subsection{Equity liquidity and firm performance}

To test the validity of the third hypothesis of the paper: EQLQ improves FPER, we estimate two models of performance by using both proxies of equity liquidity. Table 5 presents the estimation results of the panel regression models. Consistent with table 4, in Model 1, we consider PS-liquidity measure, whereas, in Model 3, we consider AM-liquidity measure. The estimation results suggest that EQLQ has a positive impact on the performance of firms. The estimated coefficient also appears statistically significant at the $1 \%$ level. This finding holds for both proxies of EQLQ used in the study, ensuring that the performance effects of liquidity are not driven by any specific measure of EQLQ. Looking at the estimates of the diagnostic tests, we find that the instruments are valid and the residuals are free from the problem of second order serial correlations. Further, it is strong evidence of the presence of first order serial correlations, confirming the validity of the estimation of the dynamic model of performance. The persistence in firm performance is also confirmed by the positive and significant value of the coefficient of a one-period lag of performance proxy (ROA) in all estimated models. These findings suggest that firms that perform well in one year are highly likely to perform better in the subsequent year.

It can be observed from the table that the estimated coefficient of PSliquidity measure in the performance model is significantly positive, implying that firms having more liquid stocks show better financial performance. The evidence on the performance-enhancing role of EQLQ is consistent with the view that improved EQLQ results in better governance mechanism at firm level, which, in turn, improves overall financial performance of the firm. The positive impact of EQLQ on FPER can also be justified based on the informational efficiency channel. It is well established in literature that enhanced EQLQ improves information production and quality regarding stock prices. Further, it enables insiders to get more incentives by creating firm value. Given this, EQLQ is considered as an essential factor for enhancing firm performance. Finally, since EQLQ enhances the involvement of shareholders in decision-making, it significantly improves the overall financial performance of firms. Our finding of the 
M. Karim and A. Rashid

Table 4: Financial development and equity liquidly effects on investment (FINV)

\begin{tabular}{|c|c|c|c|c|}
\hline & \multirow{2}{*}{\multicolumn{2}{|c|}{$\begin{array}{cc}1 & 2 \\
\text { PS-liquidity measure }\end{array}$}} & \multirow{2}{*}{\multicolumn{2}{|c|}{$\begin{array}{cc}3 & 4 \\
\text { AM-liquidity measure }\end{array}$}} \\
\hline & & & & \\
\hline & Coff./Std. & Coff./Std. & Coff./Std. & Coff./Std. \\
\hline \multirow[t]{2}{*}{ Liquidity } & $0.495^{* * *}$ & $0.565^{* * *}$ & $0.443^{* * *}$ & $0.576^{* * *}$ \\
\hline & $(0.0110)$ & $(0.0100)$ & $(0.0051)$ & $(0.0160)$ \\
\hline \multirow[t]{2}{*}{ Liquidity $\times$ FSD } & & $-0.014^{* * *}$ & & $-0.018^{* * *}$ \\
\hline & & $(0.0012)$ & & $(0.0013)$ \\
\hline \multirow[t]{2}{*}{ FSD } & & $0.021 * *$ & & $0.023^{* *}$ \\
\hline & & $(0.0100)$ & & $(0.0090)$ \\
\hline \multirow[t]{2}{*}{ Investment } & $0.676^{* * *}$ & $0.612^{* * *}$ & $0.549 * * *$ & $0.515^{* * *}$ \\
\hline & $(0.0014)$ & $(0.0020)$ & $(0.0003)$ & $(0.0009)$ \\
\hline \multirow[t]{2}{*}{ Cash Flow } & $0.332^{* * *}$ & $0.376^{* * *}$ & $0.294^{* * *}$ & $0.318^{* * *}$ \\
\hline & $(0.0012)$ & $(0.0013)$ & $(0.0015)$ & $(0.0017)$ \\
\hline \multirow[t]{2}{*}{ Tobin's Q } & $0.275^{* * *}$ & $0.187^{* * *}$ & $0.304^{* * *}$ & $0.297^{* * *}$ \\
\hline & $(0.0223)$ & $(0.0254)$ & $(0.0341)$ & $(0.0301)$ \\
\hline \multirow[t]{2}{*}{ Size } & $0.234^{* * *}$ & $0.229 * * *$ & $0.264^{* * *}$ & $0.210^{* * *}$ \\
\hline & $(0.0002)$ & $(0.0008)$ & $(0.0003)$ & $(0.0014)$ \\
\hline \multirow[t]{2}{*}{ Leverage } & $0.072^{* *}$ & $-0.086^{* *}$ & $-0.114^{* *}$ & $-0.098^{* *}$ \\
\hline & $(0.029)$ & $(0.0370)$ & $(0.0460)$ & $(0.0420)$ \\
\hline \multirow[t]{2}{*}{ Cash Holding } & $-0.218^{* * *}$ & $-0.373^{* * *}$ & $-0.356^{* * *}$ & $-0.432 * * *$ \\
\hline & $(0.0020)$ & $(0.0038)$ & $(0.0019)$ & $(0.0029)$ \\
\hline \multirow[t]{2}{*}{ Dividend Ratio } & $-0.212^{* * *}$ & $-0.367 * * *$ & $-0.192^{* * *}$ & $-0.324 * * *$ \\
\hline & $(0.0008)$ & $(0.0047)$ & $(0.0009)$ & $(0.0033)$ \\
\hline \multirow[t]{2}{*}{ Age } & $-0.009 * * *$ & $-0.010 * * *$ & $-0.007 * * *$ & $-0.006^{* * *}$ \\
\hline & $(0.0000)$ & $(0.0000)$ & $(0.0000)$ & $(0.0000)$ \\
\hline \multirow[t]{2}{*}{ Business Risk } & $-0.132^{* *}$ & $-0.139 * *$ & $-0.098^{* *}$ & $-0.092^{* *}$ \\
\hline & $(0.0610)$ & $(0.0591)$ & $(0.0431)$ & $(0.0422)$ \\
\hline \multirow[t]{2}{*}{ Constant } & $0.131^{* * *}$ & $0.154^{* * *}$ & $0.198^{* * *}$ & $0.123^{* * *}$ \\
\hline & $(0.0021)$ & $(0.0085)$ & $(0.0087)$ & $(0.0082)$ \\
\hline Firms & 360 & 360 & 360 & 360 \\
\hline Observations & 4103 & 4103 & 4103 & 4103 \\
\hline Instruments & 240 & 215 & 287 & 290 \\
\hline $\operatorname{AR}(1)$ & -25.65 & -28.87 & -34.54 & -32.39 \\
\hline $\mathrm{p}$-value & 0 & 0 & 0 & 0 \\
\hline $\operatorname{AR}(2)$ & 0.827 & 0.305 & 1.614 & -1.317 \\
\hline p-value & 0.259 & 0.643 & 0.585 & 0.264 \\
\hline Hansen & 227.075 & 236.811 & 131.137 & 98.865 \\
\hline p-value & 0.442 & 0.325 & 0.429 & 0.365 \\
\hline
\end{tabular}

positive effect of EQLQ on FPER confirms the findings of several other studies (Udomsirikul et al 2011; Amihud and Mendelson 1986; Sharma and Carney 2012). Further, this finding confirms the validity of the third hypothesis of the study.

The results given in table 5 indicate that the coefficients of control variables viz. the free cash flow, Tobin's Q, firm size, firm leverage, and tangibility are all positive and significant, whereas, cash holding, firm leverage, and age are negatively related to FPER. These findings suggest that large firms and firms that use more debt in their capital structure perform better in terms of ROA. Likewise, firms having more tangible assets as a percentage of total assets also have higher ROA. Further, our results also indicate that firms having more free 
Equity liquidity, firm investment and financial performance...

cash show better financial performance. We show that business risk is positively related to FPER. Said differently, the higher the business risk, the higher the FPER. The positive effect of business risk is also reported in some previous studies (Mirza and Javed 2013; Reddy et al 2010).

The finding regarding firm size suggests that FPER increases as a result of an

Table 5: Financial development and equity liquidity effects on ROA (FPER)

\begin{tabular}{|c|c|c|c|c|}
\hline & \multirow{2}{*}{\multicolumn{2}{|c|}{$\begin{array}{cc}1 & 2 \\
\text { PS-liquidity } & \text { measure }\end{array}$}} & \multirow{2}{*}{\multicolumn{2}{|c|}{$\begin{array}{cc}3 & 4 \\
\text { AM-liquidity } & \text { measure }\end{array}$}} \\
\hline & & & & \\
\hline & Coff./Std. & Coff./Std. & Coff./Std. & Coff./Std. \\
\hline \multirow[t]{2}{*}{ Liquidity } & $0.317 * * *$ & $0.259^{* * *}$ & $0.745^{* * *}$ & $1.212^{* * *}$ \\
\hline & $(0.0019)$ & $(0.0026)$ & $(0.0063)$ & $(0.0084)$ \\
\hline \multirow[t]{2}{*}{ Liquidity $\times$ FSD } & & $-0.154^{* * *}$ & & $-0.127 * * *$ \\
\hline & & $(0.0354)$ & & $(0.02654)$ \\
\hline \multirow[t]{2}{*}{ FSD } & & $0.376^{* *}$ & & $0.269 * * *$ \\
\hline & & $(0.1503)$ & & $(0.122)$ \\
\hline \multirow[t]{2}{*}{$\mathrm{ROA}$} & $0.052^{* * *}$ & $0.048 * * *$ & $0.057^{* * *}$ & $0.043^{* * *}$ \\
\hline & $(0.0007)$ & $(0.0009)$ & $(0.0004)$ & $(0.0002)$ \\
\hline \multirow[t]{2}{*}{ Cash Flow } & $0.354^{* * *}$ & $0.475^{* * *}$ & $0.543^{* * *}$ & $0.676^{* * *}$ \\
\hline & $(0.0035)$ & $(0.0065)$ & $(0.0047)$ & $(0.0072)$ \\
\hline \multirow[t]{2}{*}{ Tobin's Q } & $0.028 * * *$ & $0.034^{* * *}$ & $0.029 * * *$ & $0.037 * * *$ \\
\hline & $(0.0008)$ & $(0.0005)$ & $(0.0004)$ & $(0.0002)$ \\
\hline \multirow[t]{2}{*}{ Tangibility } & $1.454^{* * *}$ & $1.231^{* * *}$ & $1.165^{* * *}$ & $1.745^{* * *}$ \\
\hline & $(0.0092)$ & $(0.0112)$ & $(0.0154)$ & $(0.0089)$ \\
\hline \multirow[t]{2}{*}{ Size } & $0.718^{* * *}$ & $1.244^{* * *}$ & $0.875^{* * *}$ & $1.098^{* * *}$ \\
\hline & $(0.0213)$ & $(0.0316)$ & $(0.0277)$ & $(0.0192)$ \\
\hline \multirow[t]{2}{*}{ Leverage } & $0.423^{* * *}$ & $0.523^{* * *}$ & $0.387 * * *$ & $0.499 * * *$ \\
\hline & $(0.0235)$ & $(0.0482)$ & $(0.0376)$ & $(0.029)$ \\
\hline \multirow[t]{2}{*}{ Cash Holding } & $-0.947 * * *$ & $-0.876^{* * *}$ & $-0.922^{* * *}$ & $-0.739 * * *$ \\
\hline & $(0.0011)$ & $(0.0012)$ & $(0.0019)$ & $(0.0021)$ \\
\hline \multirow[t]{2}{*}{ Age } & $-0.042^{* * *}$ & $-0.029^{* * *}$ & $-0.041^{* * *}$ & $-0.031^{* * *}$ \\
\hline & $(0.0042)$ & $(0.0036)$ & $(0.0039)$ & $(0.0032)$ \\
\hline \multirow[t]{2}{*}{ Business Risk } & $0.2531^{* * *}$ & $0.2873^{* * *}$ & $0.317 * * *$ & $0.254^{* * *}$ \\
\hline & $(0.0015)$ & $(0.0017)$ & $(0.0027)$ & $(0.0022)$ \\
\hline \multirow[t]{2}{*}{ Constant } & $1.906 * *$ & $1.887^{* *}$ & $2.164^{* *}$ & $2.575^{* *}$ \\
\hline & $(0.6721)$ & $(0.6852)$ & $(0.8893)$ & $(0.9675)$ \\
\hline Firms & 360 & 360 & 360 & 360 \\
\hline Observations & 4100 & 4100 & 4100 & 4100 \\
\hline Instruments & 265 & 218 & 210 & 225 \\
\hline $\mathrm{AR}(1)$ & -26.75 & -27.45 & -34.87 & -31.93 \\
\hline p-value & 0 & 0 & 0 & 0 \\
\hline $\mathrm{AR}(2)$ & 1.35 & 1.13 & 1.87 & 0.98 \\
\hline $\mathrm{p}$-value & 0.282 & 0.265 & 0.287 & 0.31 \\
\hline Hansen & 127.65 & 98.72 & 123.76 & 105.27 \\
\hline p-value & 0.254 & 0.279 & 0.35 & 0.449 \\
\hline
\end{tabular}

increase in firm size. One of the possible explanations for this effect is that largesized firms generally have high-quality human capital and enjoy more economies of scale and scope. Therefore, they show better financial performance. Consistent with our results, several studies in literature like Wernerfelt et al. (1988, 1989) and Hansen and Wernerfelt (1989) have also found that FPER improves

Business Review: (2020) 15(2):51-74 
with firm size. Similarly, firms having more internally generated funds do not face any hurdle to finance their investment and thus, they perform well. Firms with higher growth opportunities generally do more investments and thus, have higher financial performance. Highly leveraged firms may enjoy more debt tax shield and consequently, exhibit higher financial performance. Yet, we are of the view that firms holding more cash in their reserves do less expenditure on their capital and other operating assets. Therefore, they perform relatively poorly. Older firms may become more vigilant in risk-taking and making investment decisions. Hence, they may not perform well compared to relatively young firms.

The results of the model of firm performance where we include AM-liquidity measure are generally similar to the findings of the model where we include SP-liquidity measure. Specifically, we show that the EQLQ measure of Amihud (2002) has significant positive effects on FPER. This indicates that the positive EQLQ effects on performance are robust to different proxies of liquidity. The results of firm-specific control variables mainly match our earlier findings.

4.6 Equity liquidity-performance relationship: The impact of financial development

To study the EQLQ effects on FPER conditional on the level of FSD, we estimate "the interacted model" given in Eq. (4). The estimation results are given in table 5 under the heading of "Model 2" and "Model 4". The diagnostic tests confirm the validity of the instruments and the absence of the second serial correlations. Further, the estimated coefficient of lagged FPER is positive and significant in both models, indicating the dynamic nature of the model and the presence of the persistence in FPER. The findings of the control variables are also similar to our early findings.

Turning to the variable of interest, we observe that the coefficient of the interaction term between FSD and EQLQ measures is significantly negative, although the own effect of EQLQ measure is positive. This finding is consistent with our fourth hypothesis, which states that improved FSD decreases the positive impact of EQLQ on FPER. These findings imply that the positive influence of EQLQ on the performance of firms becomes weaker when FSD occurs. A possible explanation for such a finding is that FSD may make easy access to debt markets for firms and thus, in turn, the reliance on the issuance of new equity to finance investment decreases. FSD may increase the informational efficiency and help improve firm-level decision-making regarding investing and financing. Hence, the positive sensitivity of FPER to EQLQ decreases. The results also reveal that FSD is positively associated with the financial performance of firms. This finding implies that FPER increases as a result of an improvement in FSD. Availability of funds, easy access to capital markets, better and well-defined rules and regulations, higher and healthy competition among financial institutions due to enhanced FSD help produce an investment friendly environment, which, in turn, enhances firms' financial and economic performance. 
Equity liquidity, firm investment and financial performance...

\section{Conclusions and policy implications}

This paper empirically examines the EQLQ impacts on Pakistani non-financial firms' investment decisions and financial performance for the period 2001-2018. It also aims to study whether improved FSD reduces the value of EQLQ for determining the investment decisions and financial performance of corporate firms. We apply the system-GMM estimator to take into consideration the dynamic nature and combat the problem of endogeneity in the models. Two different measures of EQLQ namely, PS-liquidity measure and AM-liquidity are considered to ensure that the effects of EQLQ are not driven by any specific measure of stock liquidity.

We show that EQLQ has significant and positive effects on investment decisions, suggesting that firms with liquid stocks do more investment. Firms do so as they may easily raise required amounts of capital by issuing new equities since their stocks are liquid and investors demand fewer premiums, which decreases costs of capital. The positive sensitivity of FINV to EQLQ is consistent with the informational efficiency channel and the liquidity premium hypothesis. The positive equity-liquidity relation can also be attributed to the fact that improved EQLQ widens the opportunity set of potential investments, enabling firms to do more investment in capital assets. Finally, the investment-favoring effect of EQLQ is also consistent with the view that increased liquidity alleviates financial constraints and hence, firms having liquid stocks can easily obtain required amount of capital to capitalize available investment opportunities. The evidence of the positive effect on FINV of EQLQ validates our first hypothesis.

The results regarding firm financial performance reveal that, consistent with our prediction, improved EQLQ has positive and significant effects on FPER. This finding holds for both measures of EQLQ used in the analysis. The positive impact of liquidity on firm performance suggests that firms with liquid stocks are more profitable and financially perform well as they may get the required capital at relatively low cost and easily by issuing new equity to finance all projects having NPVs greater than zero. The performance-enhancing role of EQLQ is consistent with view that the improved liquidity results in better governance mechanism by increasing the involvement of shareholders in decision-making, which improves overall financial performance of firms. The enhanced EQLQ also improves the information efficiency of stock prices and enables insiders to get more incentives. Given this, higher equity liquidity results in improved financial performance of firms.

The results on the moderating role of FSD in determining the EQLQ effects indicate that enhanced financial development weakens the investment-favoring and performance-encouraging role of EQLQ. This evidence is consistent with the second and fourth hypothesis of the paper: The higher the level of FSD, the lower the positive sensitivity of the investment and the financial performance to equity liquidity. This finding is consistent with the view that firms' dependence on equity decreases when debt becomes a cheaper source of financing due to FSD. Another possible justification for the moderating role of FSD in articulating the effect of equity liquidity on investment and performance is that FSD reduces the overall cost of capital by making easy, access to external capital, 
which reduces the role of equity liquidity in determining firms' investment decisions and performance. Enhanced FSD may reduce information asymmetry and adverse selection problems. Thus, firms depend less on stock prices based information while making investment decisions.

The findings of the paper have several meaningful implications for investors, firm managers, and policymakers. For investors seeking growth opportunities and better performance of firms, the findings of the paper suggest that they should invest in liquid stocks. Our findings also help investors in determining the required rate of return on liquid and illiquid stocks as firms having stocks with these characteristics have different investment policy and financial performance. Since our findings show that enhanced EQLQ is positively related to both FINV and FPER, managers should improve the liquidity of their stocks by considering appropriate strategies like cross-listing of stocks, stock splits, fulfilling all index criteria, improving quality of financial reporting, etc. Further, our findings indicate that improving EQLQ is an important factor for achieving growth objectives of firms and for enhancing financial performance. Thus, firm managers should find suitable and effective ways to enhance the liquidity of their stocks. The findings also suggest that policymakers should understand how boosting of equity liquidity is important for reducing the cost of capital, increasing the flow of stock price information, and improving the governance mechanism to encourage investment and growth process at firm level. Finally, the findings of the paper confirm the moderating role of FSD in formulating the effects of EQLQ on both FINV and FPER. The finding of the reduction in the positive sensitivity of both firm investment and performance due to FSD in the economy suggests that policymakers should design and implement financial development-enhancing policies to decrease the reliance of firms on equity issuance, especially for firms whose stocks are relatively illiquid and have limited access to debt market.

We provide robust evidence on the influential role of FSD on the EQLQ effects. However, there is a need to further explore whether, when, and how different firm-specific and market factors affect the significance of EQLQ for firms' financial and economic decision-making. For instance, it would be worthwhile to examine the effects of equity liquidity for firms of different sizes. Similarly, it would also be useful to investigate whether the effects of EQLQ are different for firms having different levels of corporate governance and facing different degree of business risks. The examination of the role of credit constraints and financial vulnerability in formulating the impacts of EQLQ is also essential to understand asymmetries in the equity liquidity effects.

\section{References}

Alhassan A, Naka A (2020) Corporate future investments and stock liquidity: Evidence from emerging markets. International Review of Economics \& Finance 65:69-83

Amihud Y (2002) Illiquidity and stock returns: cross-section and time-series effects. Journal of Financial Markets 5(1):31-56

Amihud Y, Levi S (2019) The effect of stock liquidity on the firm's investment and production. Available at SSRN 3183091 
Amihud Y, Mendelson H (1986) Asset pricing and the bid-ask spread. Journal of Financial Economics 17(2):223-249

Amihud Y, Mendelson H (1988) Liquidity and asset prices: Financial management implications. Financial Management 17:5-15

Anderson RW (2002) Capital structure, firm liquidity and growth. Tech. rep., NBB working paper

Asquith P, Mullins Jr DW (1986) Equity issues and offering dilution. Journal of Financial Economics 15(1-2):61-89

Baker M, Wurgler J (2002) Market timing and capital structure. The Journal of Finance $57(1): 1-32$

Batten J, Vo XV (2019) Liquidity and firm value in an emerging market. The Singapore Economic Review 64(02):365-376

Beck T, Levine R (2004) Stock markets, banks, and growth: Panel evidence. Journal of Banking \& Finance 28(3):423-442

Becker-Blease JR, Paul DL (2006) Stock liquidity and investment opportunities: Evidence from index additions. Financial Management 35(3):35-51

Blundell R, Bond S (1998) Initial conditions and moment restrictions in dynamic panel data models. Journal of Econometrics 87(1):115-143

Brogaard J, Li D, Xia Y (2017) Stock liquidity and default risk. Journal of Financial Economics 124(3):486-502

Butler AW, Grullon G, Weston JP (2005) Stock market liquidity and the cost of issuing equity. Journal of Financial and Quantitative Analysis 40(2):331-348

Butt HA, Virk NS (2015) Liquidity and asset prices: an empirical investigation of the nordic stock markets. European Financial Management 21(4):672-705

Chen Z, Gao K, Huang W (2020) Stock liquidity and excess leverage. Finance Research Letters $32: 101,178$

Cheung WM, Chung R, Fung S (2015) The effects of stock liquidity on firm value and corporate governance: Endogeneity and the reit experiment. Journal of Corporate Finance 35:211231

Cheung WM, Im HJ, Noe TH, Zhang B (2020) Liquidity, information production, and debtequity choice. Information Production, and Debt-Equity Choice (March 1, 2020)

Choi WG, Cook D (2006) Stock market liquidity and the macroeconomy: Evidence from japan. In: Monetary Policy with Very Low Inflation in the Pacific Rim, University of Chicago Press, pp 309-340

Chung KH, Elder J, Kim JC (2010) Corporate governance and liquidity. Journal of Financial and Quantitative Analysis 45(2):265-291

Corwin SA (2003) The determinants of underpricing for seasoned equity offers. The Journal of Finance 58(5):2249-2279

Dalvi MR, Baghi E, et al (2014) Evaluate the relationship between company performance and stock market liquidity. International Journal of Academic Research in Accounting, Finance and Management Sciences 4(1):136-144

Diamond DW, Verrecchia RE (1981) Information aggregation in a noisy rational expectations economy. Journal of Financial Economics 9(3):221-235

Dittmar A, Thakor A (2007) Why do firms issue equity? The Journal of Finance 62(1):1-54

Easley D, O'hara M (2004) Information and the cost of capital. The Journal of Finance 59(4):1553-1583

ElBannan MA (2017) Stock market liquidity, family ownership, and capital structure choices in an emerging country. Emerging Markets Review 33:201-231

Fan JP, Titman S, Twite G (2012) An international comparison of capital structure and debt maturity choices. Journal of Financial and Quantitative Analysis 47(1):23-56

Fang VW, Noe TH, Tice S (2009) Stock market liquidity and firm value. Journal of Financial Economics 94(1):150-169

Faure-Grimaud A, Gromb D (2004) Public trading and private incentives. Review of Financial Studies 17(4):985-1014

Frieder L, Martell R (2006) On capital structure and the liquidity of a firm's stock. Available at SSRN 880421

Guariglia A (2008) Internal financial constraints, external financial constraints, and investment choice: Evidence from a panel of uk firms. Journal of Banking \& Finance 32(9):17951809

Business Review: (2020) 15(2):51-74 
Hansen GS, Wernerfelt B (1989) Determinants of firm performance: The relative importance of economic and organizational factors. Strategic Management journal 10(5):399-411

Haugen RA, Baker NL (1996) Commonality in the determinants of expected stock returns. Journal of Financial Economics 41(3):401-439

Hennessy CA, Whited TM (2005) Debt dynamics. The Journal of Finance 60(3):1129-1165

Holmström B, Tirole J (1993) Market liquidity and performance monitoring. Journal of Political Economy 101(4):678-709

Hovakimian A, Hovakimian G, Tehranian H (2004) Determinants of target capital structure: The case of dual debt and equity issues. Journal of Financial Economics 71(3):517-540

Jung K, Kim YC, Stulz R (1996) Timing, investment opportunities, managerial discretion, and the security issue decision. Journal of Financial Economics 42(2):159-185

Kahn C, Winton A (1998) Ownership structure, speculation, and shareholder intervention. The Journal of Finance 53(1):99-129

Kang M, Wang W, Eom C (2017) Corporate investment and stock liquidity: Evidence on the price impact of trade. Review of Financial Economics 33(1):1-11

Kim SH, Lee KH (2014) Pricing of liquidity risks: Evidence from multiple liquidity measures. Journal of Empirical Finance 25:112-133

Kyle AS, Vila JL (1991) Noise trading and takeovers. The RAND Journal of Economics 22(1):54-71

Lipson ML, Mortal S (2009) Liquidity and capital structure. Journal of Financial Markets $12(4): 611-644$

Maug E (1998) Large shareholders as monitors: Is there a trade-off between liquidity and control? The Journal of Finance 53(1):65-98

Mikkelson WH, Partch MM (1986) Valuation effects of security offerings and the issuance process. Journal of Financial Economics 15(1-2):31-60

Mirza SA, Javed A (2013) Determinants of financial performance of a firm: Case of pakistani stock market. Journal of Economics and International Finance 5(2):43-52

Myers SC (1977) Determinants of corporate borrowing. Journal of Financial Economics $5(2): 147-175$

Nadarajah S, Ali S, Liu B, Huang A (2018) Stock liquidity, corporate governance and leverage: New panel evidence. Pacific-Basin Finance Journal 50:216-234

Noe TH (2002) Investor activism and financial market structure. The Review of Financial Studies 15(1):289-318

Ogawa K (2015) Firm investment, liquidity and bank health: A panel study of asian firms in the 2000s. Journal of Asian Economics 38:44-54

Pástor L, Stambaugh RF (2003) Liquidity risk and expected stock returns. Journal of Political Economy 111(3):642-685

Rashid A, Karim M (2018) Equity liquidity and firm investment: Evidence from pakistan. Journal of Accounting and Finance in Emerging Economies 4(2):111-122

Reddy K, Locke S, Scrimgeour F (2010) The efficacy of principle-based corporate governance practices and firm financial performance. International Journal of Managerial Finance

Sadaqat M, Butt HA (2017) Role of liquidity in explaining anomalous returns: evidence from emerging market. Business \& Economic Review 9(3):1-35

Sharma P, Carney M (2012) Value creation and performance in private family firms: Measurement and methodological issues. Family Business Review 25(3):233-242

Singh T, Gupta M, Sharma M (2015) Stock market liquidity and firm performance. Accounting $1(1): 29-36$

Soumaya H (2012) The effect of debt, firm size and liquidity on investment-cash flow sensitivity. International Journal of Accounting and Financial Reporting 2(2):2162-3082

Stulz RM, Vagias D, Van Dijk MA (2013) Do firms issue more equity when markets are more liquid? Tech. rep., National Bureau of Economic Research

Udomsirikul P, Jumreornvong S, Jiraporn P (2011) Liquidity and capital structure: The case of thailand. Journal of Multinational Financial Management 21(2):106-117

Xiong J (2016) Stock liquidity and firm investment-evidence from chinese listed companies. Journal of Business Theory and Practice 4(1):25

Zhang L, Li Y, Huang Z, Chen X (2018) Stock liquidity and firm value: evidence from china. Applied Economics Letters 25(1):47-50 